\title{
Diversity of ferns and lycophytes in Brazil
}

\author{
Jefferson Prado ${ }^{1}$, Lana da S. Sylvestre, Paulo H. Labiak, Paulo G. Windisch, Alexandre Salino, Iva C.L.
} Barros, Regina Y. Hirai, Thaís E. Almeida, Augusto C.P. Santiago, Maria A. Kieling-Rubio, Anna Flora de N. Pereira, Benjamin Øllgaard, Carla G.V. Ramos, John T. Mickel, Vinicius A.O. Dittrich, Claudine M. Mynssen, Pedro B. Schwartsburd, João Paulo S. Condack, Jovani B.S. Pereira, Fernando B. Matos

\begin{abstract}
This compilation of ferns and lycophytes in Brazil is an update of the one published in 2010 in Catálogo de Plantas e Fungos do Brasil. The methodology consisted in collecting data from regional checklists, taxonomic revisions, and selected databases. Invited specialists improved the list accessing a website housed at the Jardim Botânico do Rio de Janeiro. The results show 1,253 species: 1,111 of ferns and 142 of lycophytes. This number is $6.5 \%$ higher than the previous one $(1,176 \mathrm{spp}$.). The percentage of endemic species decreased from $38.2 \%$ to $36.7 \%$. We recognized 36 families and 133 genera (vs. 33 families, 121 genera in 2010). The 10 most diverse families are Pteridaceae (196 spp.), Dryopteridaceae (179), Polypodiaceae (164), Hymenophyllaceae (90), Thelypteridaceae (86), Aspleniaceae (78), Lycopodiaceae (64), Selaginellaceae (55), Anemiaceae (51), and Cyatheaceae (45). The three most diverse genera are still Elaphoglossum (87 spp.), Thelypteris (85), and Asplenium (74). The richest phytogeographic domain continues to be in the Atlantic Rainforest with 883 species which also has the largest number of endemic and threatened species, followed by the Amazon Rainforest (503), Cerrado (269), Pantanal (30), Caatinga (26), and Pampa (eight). Minas Gerais remains as the richest state (657 spp. vs. 580 in 2010).

Key words: Flora, Taxonomy, Endemic species, Atlantic Rainforest, Amazon Rainforest.

\section{Resumo}

Esta compilação de samambaias e licófitas do Brasil é uma atualização daquela de 2010, no Catálogo de Plantas e Fungos do Brasil. A metodologia consistiu na reunião de dados de listas regionais, revisões de grupos e bancos de dados selecionados. Especialistas convidados melhoraram a lista através do acesso a um sítio da web do Jardim Botânico do Rio Janeiro. Os resultados apontam uma diversidade de 1.253 espécies, sendo 1.111 samambaias e 142 licófitas. Este número é 6,5\% maior que o anterior (1.176 espécies). As espécies endêmicas decresceram de 38,2\% para 36,7\%. Foram reconhecidas 36 famílias e 133 gêneros (vs. 33 famílias, 121 gêneros em 2010). As dez famílias mais diversas são: Pteridaceae (196 espécies), Dryopteridaceae (179), Polypodiaceae (164), Hymenophyllaceae (90), Thelypteridaceae (86), Aspleniaceae (78), Lycopodiaceae (64), Selaginellaceae (55), Anemiaceae (51) e Cyatheaceae (45). Os três gêneros mais diversos continuam sendo Elaphoglossum (87 espécies), Thelypteris (85) e Asplenium (74). O Domínio Fitogeográfico mais rico continua sendo a Mata Atlântica (883 espécies) e também com mais espécies endêmicas e ameaçadas, seguido pela Amazônia (503 espécies), Cerrado (269), Pantanal (30), Caatinga (26) e Pampa (oito). Minas Gerais permanece como o estado com maior riqueza (657 espécies vs. 580 em 2010).

Palavras-chave: Flora, Taxonomia, Espécies endêmicas, Floresta Atlântica, Floresta Amazônica.
\end{abstract}

The full authorship of this article can be found in Appendix 1 .

${ }^{1}$ Author for correspondence: jprado.01@uol.com.br 


\section{Introduction}

The publication of the list of ferns and lycophytes of Brazil in 2010 (Prado \& Sylvestre 2010) represented a major advance in the knowledge of these groups of plants in the country. Until that date there was no detailed compilation of the diversity of these plants, other than that published in the Flora Brasiliensis by Martius \& Eichler, whose treatments were developed by Spring (1840 Lycopodineae), Sturm (1859 Ophioglossaceae, Marattiaceae, Osmundaceae, Schizaeceae, Gleicheniaceae, and Hymenophyllaceae), and Baker (1870, Cyatheaceae and Polypodiaceae). This flora had recognized 576 species, representing less than half of the number of species currently known.

Since the publication of the Flora Brasiliensis, major advances in the knowledge of ferns and lycophytes have been reported in a fragmented way, through the publication of regional floras, taxonomic revisions of groups, checklists, as well as descriptions of new taxa. These data were compiled and included in the first version of the Catálogo de Plantas e Fungos do Brasil, which reported the occurrence of 1,176 species, being 123 of lycophytes and 1,053 of ferns (Prado \& Sylvestre 2010).

After this compilation, new studies appeared, presenting taxonomic and nomenclatural novelties, such as (in alphabetical order of family): Mickel (2015, in press) which dealt with the taxonomic revision of Anemia (Anemiaceae), a very diverse and well represented group in Brazil; Lehnert (2012) studied species of Cyathea 1-2-pinnate (Cyatheaceae) and Lehnert \& Weigand (2013) presented a review of Cyathea corcovadensis group; Schwartsburd \& Prado (2014) presented a review of Hypolepis rugosula group (Dennstaedtiaceae) and Schwartsburd et al. (2014) revealed the occurrence of new taxa of Pteridium (Dennstaedtiaceae) in Brazil.

Regarding the Dryopteridaceae, one of the richest families in Brazil, we highlight the studies by Vasco (2011) and Vasco et al. (2013) on Elaphoglossum subsection Muscosa and section Squamipedia; Matos \& Mickel (2014), who reviewed Elaphoglossum section Polytrichia; Sundue et al. (2013) presented a synopsis of Rumohra in Brazil, with the description of a new species and Prado et al. (2014) demonstrated the occurrence of another species of Dryopteris in Brazil, also treating the genus in the country.

In Gleicheniaceae, the revision of Sticherus published by Gonzales \& Kessler (2011), brought new combinations that have altered the diversity of this group in Brazil.

In Polypodiaceae, several taxonomic revisions have been published, especially for the group of the grammitid ferns, with the description of new genera and species. The new genera Leucotrichum (Labiak et al. 2010) and Stenogrammitis (Labiak 2011) were segregated from Lellingeria. Hirai et al. (2011) described Moranopteris and later Hirai \& Prado (2012) presented a taxonomic revision for this genus. Finally, Labiak (2013), Lehnert (2013), and Moguel-Velázquez \& Kessler (2013) presented the revisions of the genera Lellingeria, Melpomene, and Alansmia, respectively, in a single volume of the Flora Neotropica series.

For the Pteridaceae, Link-Pérez \& Hickey (2011) reviewed the group of Adiantopsis radiata and for Brazil they described a new species $(A$. timida Link-Pérez \& Hickey) and recognized another one (A. trifurcata (Baker) Link-Pérez \& Hickey). Cochran et al. (2014) described a new genus (Tryonia), segregated from Eriosorus/ Jamesonia to the Brazilian Atlantic Rainforest.

More specific contributions, such as descriptions of new taxa, also added new names to the list of ferns and lycophytes of Brazil and improved the estimates of the diversity of the group: in Athyriaceae, new species in Diplazium (Mynssen \& Matos 2012; Mynssen \& Sylvestre 2013); in Blechnaceae, a new species of Blechnum (Dittrich et al. 2012); in Dennstaedtiaceae, new species of Hypolepis (Schwartsburd et al. 2012); in Dryopteridaceae, a new genus (Mickelia) and several new combinations (Moran et al. 2010), and new species for Elaphoglossum (Kieling-Rubio \& Windisch 2012; Melo \& Salino 2012); in Isoetaceae, new species of Isoetes (Pereira et al. 2012; Pereira \& Labiak 2013); in Lycopodiaceae, new species and new combinations of Diphasiastrum, Lycopodiella, Phlegmariurus, and Pseudolycopodiella (Øllgaard 2012a; Øllgaard 2012b); in Polypodiaceae, nomenclatural novelties in Pleopeltis (Prado \& Hirai 2011; Schwartsburd 2014), and nomenclatural novelties and new species of Serpocaulon (Schwartsburd \& Smith 2013) and Stenogrammitis (Labiak 2011); in Pteridaceae, also nomenclatural novelties in Adiantopsis (Schuettpelz et al. 2014), a new species in Adiantum (Prado \& Hirai 2013), and nomenclatural novelties in Jamesonia (Christenhusz et al. 2011); in Thelypteridaceae, new species in Thelypteris (Matos et al. 2010; Salino et al. 2011; Salino et al. 2014). 
Floristic surveys have also contributed to the increased knowledge of the group, contributing new names to the list of ferns and lycophytes of Brazil. Biral \& Prado (2012) revealed the occurrence of Pellaea ovata (Desv.) Weath. in São Paulo State, previously known only to the Andean region. Carvalho et al. (2012) reported the occurrence of several species of Pico da Neblina Massif region known only from the Venezuelan side that had not been yet cited for Brazil. Cnemidaria spectabilis (Kunze) R.M. Tryon var. spectabilis [Cyathea spectabilis (Kunze) Domin] was recorded for the Brazilian Amazon area for the first time by Góes-Neto \& Pietrobom (2012). It was previously known only for neighbouring countries of Brazil, such as: Venezuela, Guyana, Suriname, and French Guiana.

The main goals of this new compilation for ferns and lycophytes of Brazil are to refine the data gathered and correct any misconceptions published for the group in the Catálogo de Plantas e Fungos do Brasil (Prado \& Sylvestre 2010), and contribute with new information on Brazilian plant diversity.

\section{Methodology}

The methodology used in this study was basically the same as that adopted for the other groups enumerated by Forzza et al. (2010). Regional lists and selected databases were consolidated and made available to the invited experts on a website at the Jardim Botânico do Rio de Janeiro. Each expert had the task to include new records and modify data from previous records in the light of the latest knowledge for his/her speciality group. The responsibility of the coordinators of the group of ferns and lycophytes was to check and complete the data that eventually was not included by experts. Further details regarding the preparation of the new version of the Brazilian List, which was updated until March 2015 can be found in BFG (2015).

The complete dataset used for the present analyses can be found as the Brazilian List of Ferns and Lycophytes (see supplementary material $<\mathrm{http}$ :// dx.doi.org/10.6084/m9.figshare.1538650> - DOI: 10.1590/2175-7860201566410).

The 20 experts who participated in this step contributed to the updates in the following families (authors are listed in order of authorship): Anemiaceae (J.T. Mickel, I.C.L. Barros, A.C.P. Santiago, A.F.N. Pereira \& P.H. Labiak), Aspleniaceae (L.S. Sylvestre), Athyriaceae (C.M. Mynssen), Blechnaceae (V.A.O. Dittrich \& A. Salino), Culcitaceae (J.P.S. Condack), Cyatheaceae (P.G. Windisch \& A.C.P. Santiago),
Cystopteridaceae (C.M. Mynssen), Dennstaedtiaceae (P.B. Schwartsburd), Dicksoniaceae (J.P.S. Condack), Dryopteridacae (J. Prado, L.S. Sylvestre, A. Salino, J.P.S. Condack, P.G. Windisch, R.Y. Hirai, T.E. Almeida \& M.A. Kieling-Rubio), Equisetaceae (A. Salino \& T.E. Almeida), Gleicheniaceae (F.B. Matos), Hemidictyaceae (C.M. Mynssen), Hymenophyllaceae (P.G. Windisch), Isoetaceae (J.B. Pereira, J. Prado \& L.S. Sylvestre), Lindsaeaceae (J. Prado), Lomariopsidaceae (I.C.L. Barros, A.C.P. Santiago \& A.F.N. Pereira), Lycopodiaceae (P.G. Windisch, C.G.V. Ramos \& B. Øllgaard), Lygodiaceae (I.C.L. Barros, A.C.P. Santiago \& A.F.N. Pereira), Marattiaceae (P.H. Labiak), Marsileaceae (P.G. Windisch), Metaxyaceae (L.S. Sylvestre), Oleandraceae (L.S. Sylvestre), Ophioglossaceae (J.P.S. Condack \& L.S. Sylvestre), Osmundaceae (L.S. Sylvestre), Plagiogyriaceae (J.P.S. Condack), Polypodiaceae (P.H. Labiak, R.Y. Hirai \& T.E. Almeida), Psilotaceae (L.S. Sylvestre), Pteridaceae (J. Prado), Saccolomataceae (P.B. Schwartsburd), Salviniaceae (A. Salino \& T.E. Almeida), Schizaeaceae (I.C.L. Barros, A.C.P. Santiago \& A.F.N. Pereira), Selaginellaceae (R.Y. Hirai), Tectariaceae (J. Prado), Thelypteridaceae (A. Salino \& T.E. Almeida), and Woodsiaceae (C.M. Mynssen).

\section{Results}

The diversity of ferns and lycophytes, in this compilation (see Brazilian List of Ferns and Lycophytes; supplementary material - DOI: Xxxxxx), adds up to a total of 1,253 species, divided between 1,111 ferns and 142 lycophytes. This number is $6.5 \%$ higher than the previous one, which was 1,176

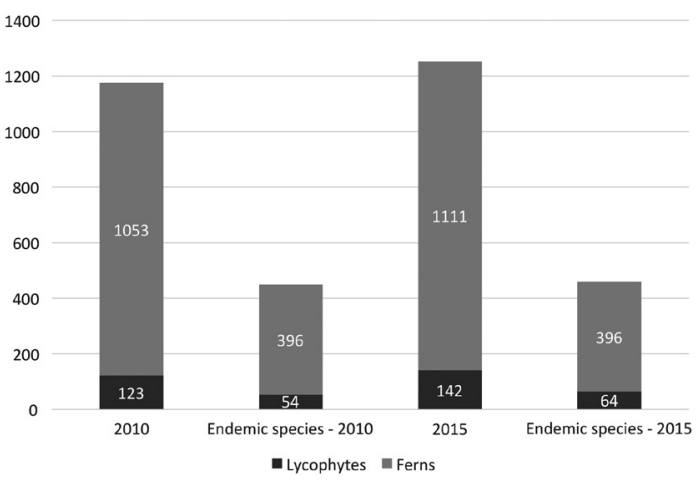

Figure 1-Comparison between the number of species and the number of endemic species of lycophytes and ferns between the 2010 and the 2015 versions of the Brazilian List. 
species (Prado \& Sylvestre 2010) (Fig. 1). Due to recent advances in the classifications of groups (e.g., Moran et al. 2010 and Øllgaard 2012a, and others), 36 families and 133 genera are currently recognized, as opposed to 33 families and 121 genera listed in the 2010 Catalogue.

The ten most diverse families are: Pteridaceae, with 196 species, followed by Dryopteridaceae (179), Polypodiaceae (164), Hymenophyllaceae (90), Thelypteridaceae (86), Aspleniaceae (78), Lycopodiaceae (64), Selaginellaceae (55) Anemiaceae (51), and Cyatheaceae (45) (Fig. 2). Based on these results, further changes in the 2010 data include: Hymenophyllaceae now exceed Thelypteridaceae in number of species; Lycopodiaceae exceeds Anemiaceae and Selaginellaceae, while the number of species of Anemiaceae has been reduced with relation to 2010 (Fig. 2). The 36 other families occurring in Brazil are represented by numbers ranging from 32 to one species.

With respect to the information published by Prado \& Sylvestre (2010), the percentage of endemic species had a small decrease, from $38.2 \%$ (450 endemic species of 1,176 species) in 2010 to $36.7 \%$ (460 of 1,253) in this compilation.
However, among the ten families with the highest number of endemic taxa, Dryopteridaceae remained the richest, with 89 endemic species, followed by Polypodiaceae (72), Pteridaceae (71), Thelypteridaceae (38), Lycopodiaceae (31), Anemiaceae (30), Aspleniaceae (23), Selaginellaceae (15), and Cyatheaceae (14) (Fig. 2 ). There were also changes to the 2010 data regarding the Lycopodiaceae, which surpassed Anemiaceae, Selaginellaceae, and Cyatheaceae; and in Hymenophyllaceae where there was a reduction in the number of endemic taxa. On the other hand, Isoetaceae and Athyriaceae (with 18 and 11 species, respectively), which are not among the ten richest families in Brazilian flora, have a high number of endemic species (Tab. 1, genera Isoetes and Diplazium). The other families have numbers ranging from less than 10 endemic species to none.

As mentioned earlier, 133 genera have been recognized in this study, with the 20 genera most diverse encompassing 804 species, 306 of them endemic (Tab. 1). As in the previous study, the three most diverse genera remain Elaphoglossum (87 species), Thelypteris (85), and Asplenium

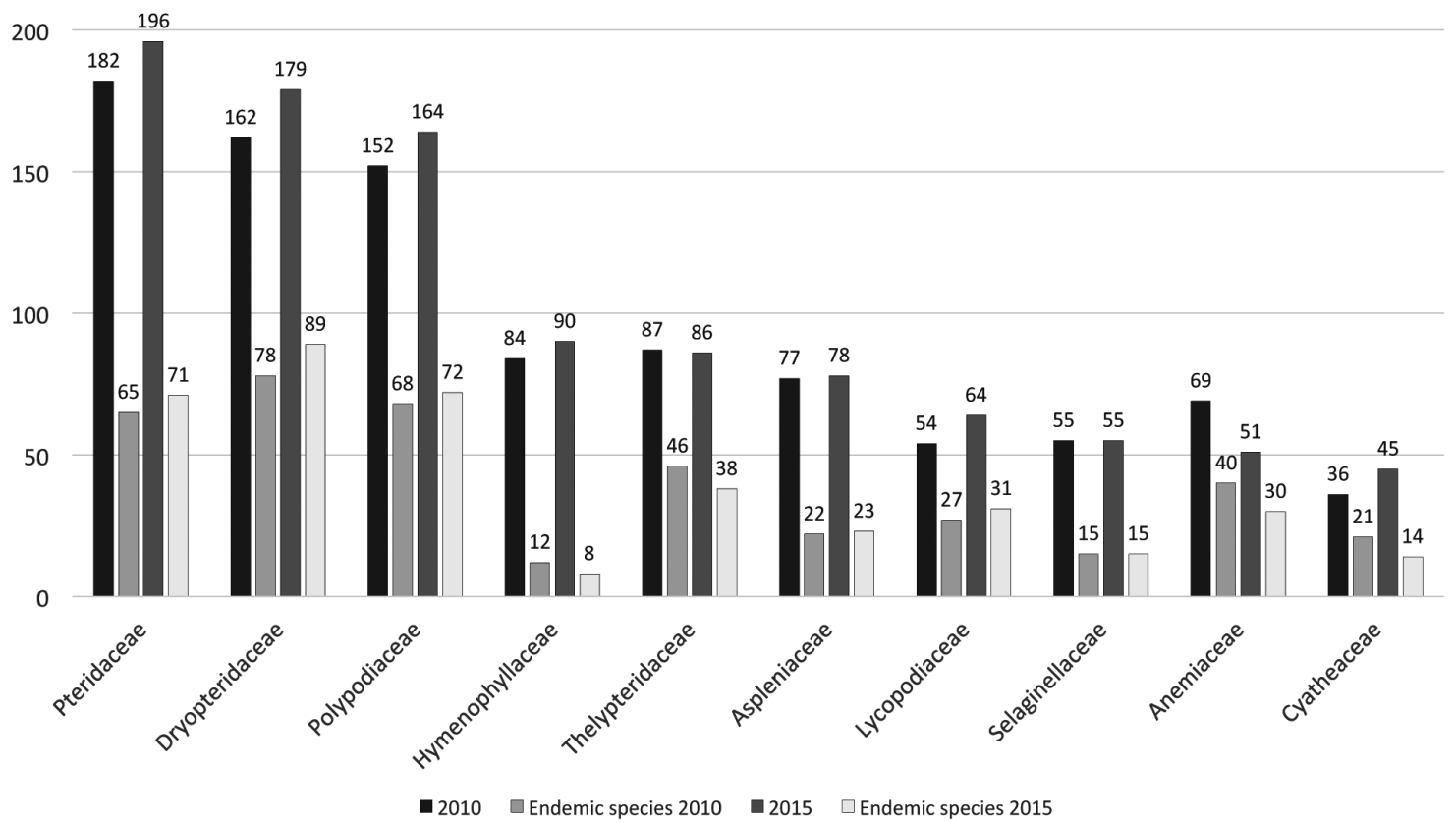

Figure 2 - The ten most diverse families of ferns and lycophytes (total number of species and endemic species) in 2010 and 2015. 
Table 1 - Ferns and lycophytes of the twenty richest genera. Each genus is cited with their number of species and number of endemic species in the first version of the Species List of Flora of Brazil (Prado \& Sylvestre 2010) and the current list (2015).

\begin{tabular}{|c|c|c|c|c|}
\hline Genera & N. of species 2015 & N. of endemic 2015 & N. of species 2010 & N. of endemic 2010 \\
\hline Elaphoglossum & 87 & 41 & 78 & 35 \\
\hline Thelypteris & 85 & 38 & 86 & 46 \\
\hline Asplenium & 74 & 23 & 77 & 22 \\
\hline Adiantum & 63 & 19 & 62 & 18 \\
\hline Selaginella & 55 & 15 & 55 & 15 \\
\hline Anemia & 51 & 30 & 69 & 40 \\
\hline Phlegmariurus & 40 & 23 & $38^{*}$ & $25^{*}$ \\
\hline Cyathea & 39 & 13 & 30 & 19 \\
\hline Trichomanes & 35 & 0 & 33 & 2 \\
\hline Doryopteris & 32 & 20 & 27 & 16 \\
\hline Hymenophyllum & 32 & 7 & 29 & 8 \\
\hline Lindsaea & 32 & 7 & 27 & 5 \\
\hline Blechnum & 30 & 8 & 27 & 8 \\
\hline Diplazium & 25 & 11 & 22 & 8 \\
\hline Pteris & 24 & 6 & 22 & 6 \\
\hline Isoetes & 23 & 18 & 14 & 12 \\
\hline Campyloneurum & 22 & 6 & 21 & 5 \\
\hline Pecluma & 19 & 7 & 18 & 8 \\
\hline Megalastrum & 18 & 13 & 18 & 13 \\
\hline Microgramma & 18 & 1 & 18 & 1 \\
\hline Total & 804 & 306 & 771 & 312 \\
\hline
\end{tabular}

(74). However, it is noteworthy that the number of species in Elaphoglossum had the highest increase between the first and the second study (from 78 species in 2010 to 87 in 2015), representing an increment of $11.5 \%$. Allied to this increase, the number of endemic species in this genus also increased from 35 to 41 . Other numerical variations that stood out occurred in Anemia, which had 69 species (40 endemic) in 2010 and was reduced to 51 (30 endemic) in 2015; in Cyathea, which jumped from 30 species (19 endemic) to 39 (13 endemic); Doryopteris, previously with 27 species (16 endemic), has now 32 (20 endemic), and Ctenitis, which was among the most diverse genera in 2010 (with 17 species, 10 endemic), and was surpassed by Isoetes, now with 23 species (18 endemic).

Due to changes in the classification of Lycopodiaceae, most of the species of the genus
Huperzia occurring in Brazil and South America were transferred to Phlegmariurus. Currently, Huperzia is represented in Brazil by a single endemic species, Huperzia catharinae (Christ) Holub, while in 2010 this genus comprised 38 species, 25 endemic to Brazil. In the current compilation, the species previously mentioned in Huperzia appear in the genus Phlegmariurus (40 species, 23 endemic) (Tab. 1).

The Brazilian biome with the highest number of species continues to be the Atlantic Rainforest, with 883 species, followed by the Amazon Rainforest (503 species), Cerrado (269), Pantanal (30), Caatinga (26), and Pampa (eight) (Fig. 3). It should be noted that in the 2010 the Caatinga had exceeded the Pantanal (25 and 18 species, respectively). The Atlantic Rainforest is the area with the largest number of endemic 
species, followed by the Cerrado, the latter with a concentration of endemism associated to the "Campo rupestre' vegetation type.

The greatest diversity in the Atlantic Rainforest is found in the Ombrophilous Forest, and this type of vegetation concentrates $90 \%$ of species and $58 \%$ of the endemic species found in this area. Although the Mixed Ombrophilous Forest and the Seasonally Semideciduous Forest exhibit higher species numbers than the Altitude Grassland, the latter type of vegetation accounts for a greater percentage of endemism (9\%). In the Amazon Rainforest, the greatest diversity is found in the Terra Firme Forest (313 species), with six endemic species. The 'Cerrado latu sensu' is the vegetation type with the largest number of endemic species in the Cerrado (16 species), followed by the 'Campo rupestre', where eight endemic species are recognized.

Regarding the geopolitical regions, there was an evident increase in the number of species and the Southeast region was confirmed as the most diverse, with 841 species in this survey (vs. 789 in 2010), as well as with the higher number of endemic species (131). The other regions also increased their representation: the South showed 576 species (vs. 540 species in 2010); North with 547 species (vs. 441); Northeast 502 (vs. 385), and Central-west with 394 (vs. 245) (Fig. 4).

In relation to the diversity by state, there were also some changes compared to previous data. However, Minas Gerais remained the state with the largest number of species, (657 species vs. 580 , in the previous survey). The states of Rio de Janeiro, currently with 620 species (vs. 552 species in 2010) and São Paulo, with 618 species (vs. 561), corroborate the greatest amount of species in the Southeast. Compared to the previous data, the largest additions occurred in the states of Bahia (138 species) and Espírito Santo (108), probably due to increased knowledge of the flora of these states, which admittedly are among the ten richest in the country. The fewer inclusions correspond to the northeastern states of Sergipe (19 species), Piauí (17), and Rio Grande do Norte (12), the latter state with the lowest diversity, adding up to only 20 species. Nonetheless, the number of records for these states increased very significantly, especially for Tocantins $(210 \%)$, Sergipe $(190 \%)$, and Rio Grande do Norte (150\%) (Tab. 2).

Most species occurring in Brazil are herbaceous and terrestrial (684 species), followed by epiphytes (344), rupicolous (105), aquatics

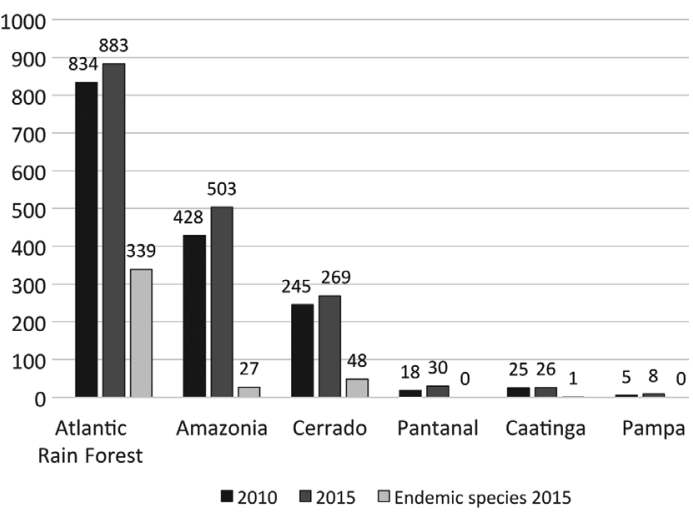

Figure 3 - Number of species of ferns and lycophytes by biome recorded in 2010, 2015, and number of endemic species per biome in 2015 .

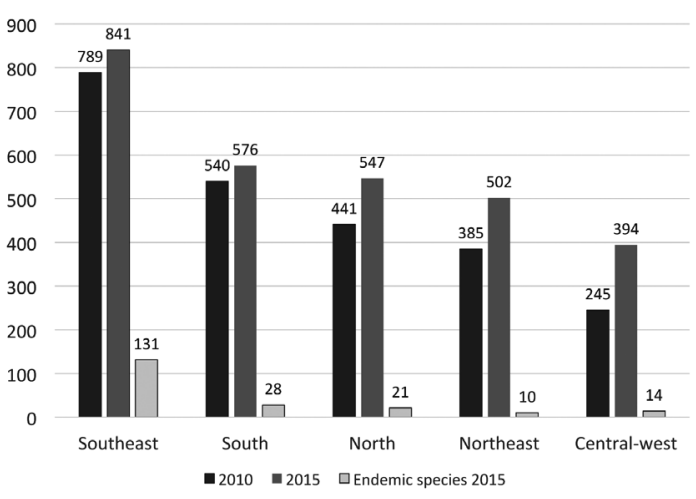

Figure 4-Number of species of ferns and lycophytes by geographic region recorded in 2010, 2015 and number of endemic species per geographic region in 2015.

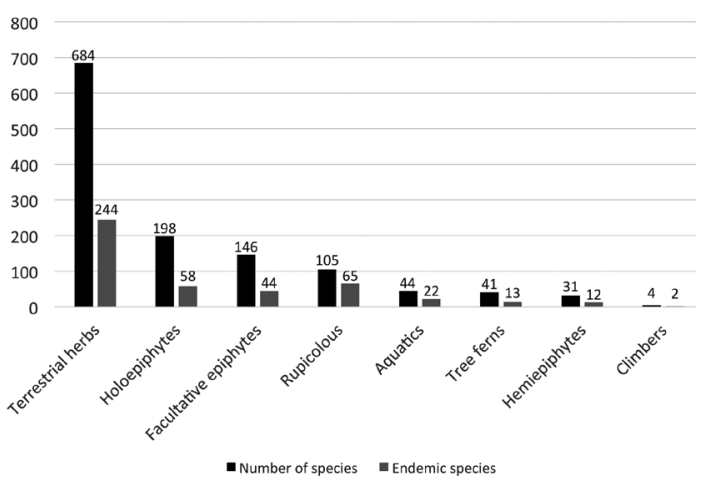

Figure 5-Number of species and endemic species of ferns and lycophytes by life form and substrate (data from 2015). 
Table 2 - Species of ferns and lycophytes in the states of Brazil. Number of species, number of endemic species, and percentage change per state (and Federal District) in the first version of the Species List flora of Brazil (Prado \& Sylvestre 2010) and current list (2015). The species endemic occur exclusively in the cited state.

\begin{tabular}{lccccc}
\hline States + Federal District & $\begin{array}{c}\text { N. of species } \\
\mathbf{2 0 1 5}\end{array}$ & $\begin{array}{c}\text { N. of endemic } \\
\mathbf{2 0 1 5}\end{array}$ & $\begin{array}{c}\text { N. of species } \\
\mathbf{2 0 1 0}\end{array}$ & $\begin{array}{c}\text { N. of endemic } \\
\mathbf{2 0 1 0}\end{array}$ & $\begin{array}{c}\text { \% change } \\
\mathbf{2 0 1 0 - 2 0 1 5}\end{array}$ \\
\hline Minas Gerais & 657 & 23 & 580 & 28 & 13.3 \\
Rio de Janeiro & 620 & 30 & 552 & 31 & 12.3 \\
São Paulo & 618 & 9 & 561 & 10 & 10.2 \\
Paraná & 491 & 1 & 426 & 2 & 15.3 \\
Santa Catarina & 467 & 2 & 402 & 7 & 16.2 \\
Bahia & 451 & 8 & 313 & 9 & 44.1 \\
Espírito Santo & 439 & 13 & 331 & 14 & 32.6 \\
Amazonas & 378 & 9 & 294 & 13 & 28.6 \\
Rio Grande do Sul & 370 & 13 & 326 & 13 & 13.5 \\
Mato Grosso & 286 & 1 & 229 & 4 & 24.9 \\
Pará & 255 & 7 & 171 & 1 & 49.1 \\
Goiás & 231 & 7 & 178 & 9 & 29.8 \\
Acre & 218 & 1 & 182 & 3 & 19.8 \\
Pernambuco & 214 & 0 & 164 & 0 & 30.5 \\
Mato Grosso do Sul & 171 & 2 & 104 & 4 & 64.4 \\
Roraima & 169 & 2 & 98 & 1 & 72.4 \\
Rondônia & 141 & 0 & 86 & 0 & 64.0 \\
Distrito Federal & 138 & 0 & 107 & 1 & 29.0 \\
Ceará & 136 & 0 & 96 & 0 & 41.7 \\
Alagoas & 115 & 0 & 65 & 0 & 76.9 \\
Amapá & 111 & 0 & 75 & 0 & 48.0 \\
Maranhão & 73 & 0 & 40 & 0 & 210.0 \\
Tocantins & 62 & 0 & 20 & 0 & 19.5 \\
Paraíba & 59 & 0 & 29 & 0 & 150.0 \\
Piaú́ & 38 & 0 & 21 & 0.0 \\
Sergipe & 29 & 0 & 10 & 0 & \\
Rio Grande do Norte & 20 & 0 & 8 & 0 & \\
\hline & & & & 0 & \\
\hline
\end{tabular}

(44), tree ferns (41), hemiepiphytes (31), and climbers (4) (Fig. 5). The arborescent habit is a hallmark in Cyatheaceae, but there are at least three species in this family that are small herbs: Hymenophyllopsis ctenitoides Lellinger, $H$. hymenophylloides L.D. Gómez, and Cyathea myriotricha (Baker) R.C. Moran \& J. Prado. The climbing species belong to Salpichlaena (Blechnaceae) and Lygodium (Lygodiaceae), while the epiphytic species are found mainly in the families
Aspleniaceae (Asplenium), Dryopteridaceae (Elaphoglossum), Hymenophyllaceae (Didymoglossum, Hymenophyllum, Polyphlebium), Lomariopsidaceae (Nephrolepis), Lycopodiaceae (Phlegmariurus), and Polypodiaceae (in almost all genera). The hemiepiphyte species are distributed in many families, especially in the genera Mickelia and Polybotrya (Dryopteridaceae), Lomariopsis (Lomariopsidaceae), and Vandenboschia (Hymenophyllaceae). Finally, aquatic plants are 
found mainly in the families Isoetaceae (Isoetes), Marsileaceae (Marsilea), Salviniaceae (Azolla and Salvinia), and Pteridaceae (Ceratopteris).

Considering the three areas with the highest number of ferns and lycophytes, the Atlantic Rainforest is the one with the greatest diversity of life forms, followed by Amazon Rainforest, and the Cerrado, while the terrestrial herbs are most commonly found in Caatinga, Pantanal, and Pampa (Fig. 6).

Most species threatened with extinction recorded in the Brazilian Red Book (Martinelli \& Moraes 2013) present restricted occurrence to a single unit of the federation. Many of these species are represented by populations distributed in areas smaller than $20 \mathrm{~km}^{2}$, and are here called 'restricted endemic' (Fig. 7). The genera that have more than ten endemic species (Tab. 1) are also the most cited in the red book. However, no species of Cyathea and
Diplazium were considered endangered, although many of them are endemic (13 and 11 species, respectively) and Cyatheaceae particularly is under pressure from the horticultural industry, and is also listed under CITES regulation worldwide. Isoetes, with 18 endemic species, is represented by a single endangered species in the Red List, indicating that more efforts may be necessary to understand these plants and their conservation requirements. As the process of evaluation of threatened species is continuous, there is an opportunity to improve the data for many families currently underestimated in the Red List.

The endemic species of the Brazilian oceanic islands have a high degree of threat. Of these, we can highlight those occurring in the Trindade Island. Many of them are listed in the Brazilian Red Book (Martinelli \& Moraes 2013), such as: Asplenium beckeri Brade, A. trindadense (Brade) Sylvestre,

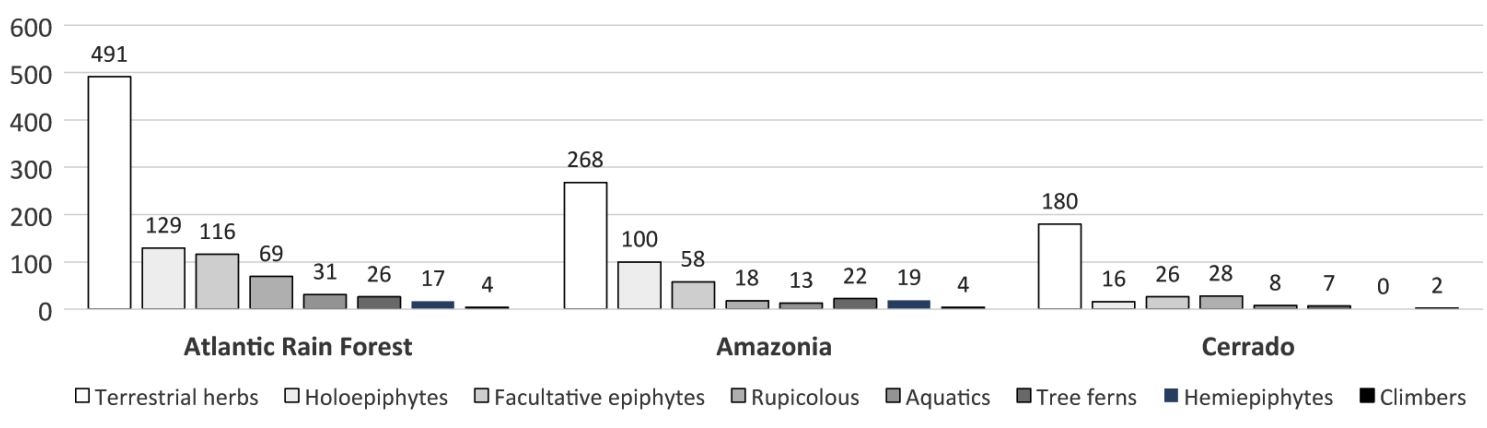

Figure 6 - Representation of life forms and substrate in the three areas with the highest number of species of ferns and lycophytes (data from 2015).

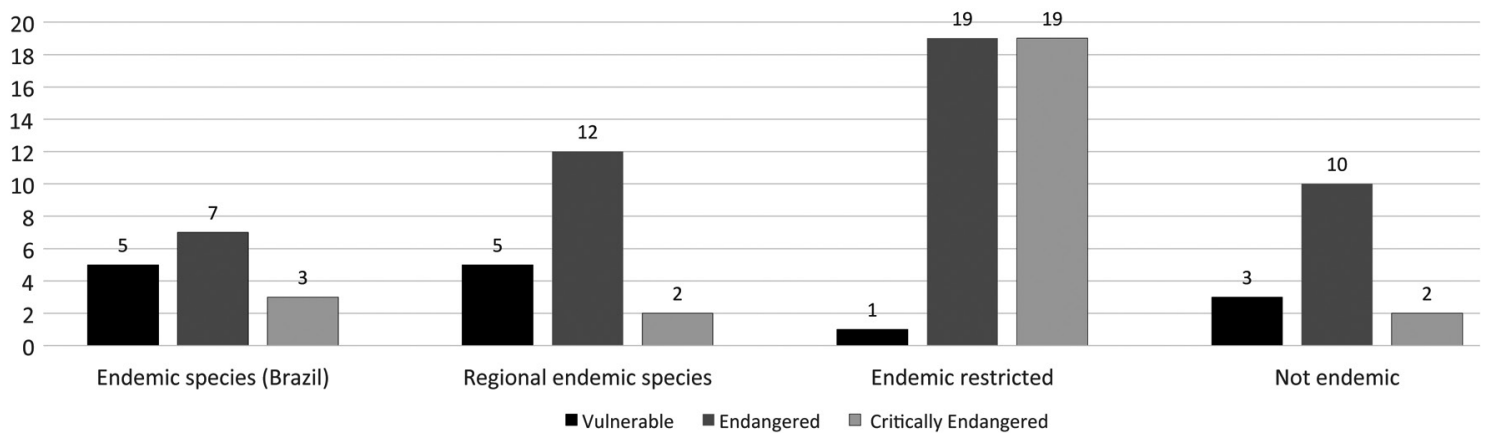

Figure 7 - Number of species in each of the three categories of extinction threats (Vulnerable, Endangered, and Critically Endangered) appearing in the Brazilian Red Book (Martinelli \& Moraes 2013), by index of endemism. Brazilian endemic species: Brazilian endemic species that occur in more than one geographical region; Regional endemic species: species with distribution restricted to a particular geographic region; Endemic restricted: species with distribution restricted to a particular unit of the Federation. 
Elaphoglossum beckeri Brade, Pecluma insularis (Brade) Salino, Pleopeltis trindadense (Brade) Salino, and Thelypteris noveana (Brade) Ponce.

\section{Discussion}

The recognition of 1,253 species of ferns and lycophytes in the Brazilian List of Plants and Fungi in 2015 represents an advance in the knowledge of the group and is probably more compatible to the actual values for its diversity. This number of species is closer to what was previously estimated by Prado (1998), who mentioned the existence of $1,200-1,300$ species of both groups in the country, while the first survey conducted in 2010 recorded 1,176 species. The current number of species recognized in 2015 is $6.5 \%$ higher than the one recorded in 2010.

The increase or decrease of species number in the current list can be attributed to recent studies that involved synopsis and taxonomic revisions. For example, in Anemia, 69 species were recognized in 2010, whereas now only 51 were accepted by Mickel (2015, in press).

On the other hand, there are groups still lacking detailed studies, not only to improve species circumscription, but also to understand their geographic distribution. The main groups that lack studies are: Aspleniaceae, Blechnaceae, Cyatheaceae, Dryopteridaceae (especially Ctenitis and Elaphoglossum), Hymenophyllaceae, Isoetaceae, Lycopodiaceae (especially Phlegmariurus), Marattiaceae, Polypodiaceae (especially Campyloneurum, Microgramma, Pecluma, and Pleopeltis), Pteridaceae (mainly Adiantum), Selaginellaceae, Tectariaceae, and Thelypteridaceae (whose species were recognized in genera that have recently been segregated from Thelypteris). For these groups, no recent treatments with identification keys, descriptions, and illustrations for the taxa occurring in Brazil exist. Some of these genera are being studied, however the data are not yet available and it is likely that the number of species comprised by these groups will change as these studies are completed.

The Brazilian Atlantic Rainforest was the area with the highest species, endemic and endangered counts. This region has being recognized as one of the biodiversity hotspots of the planet (Mittermeier et al. 1998, 2004), and likewise it had already been identified as a major primary centre of diversity and endemism for Neotropical ferns (Tryon 1972). This high diversity is attributed to different environmental conditions occurring in tropical mountainous areas, favouring the establishment of microenvironments with different characteristics and consequently an increase in floristic diversity (Moran 2008). Kessler (2010) stresses that the great diversity of ferns and lycophytes found in tropical rain forests is due especially to the high rates of evapotranspiration, associated with heavy rainfall and topographic complexity of the terrain.

\section{Conclusions}

It is believed that the information presented in the current list of ferns and lycophytes of Brazil is more accurate than those presented in 2010 . However, we still need to employ more efforts to collect data in remote areas, thus improving our knowledge of the species and their distribution in Brazil, enabling us to better understand the threat they may face.

\section{References}

Baker, G. 1870. Cyatheaceae et Polypodiaceae. In: C.F.P. Martius \& A.G. Eichler (eds.). Flora Brasiliensis. Fleischer, Leipzig. Vol. 1, part 2, pp. 305-711.

BFG. 2015. Growing knowledge: an overview of Seed Plant diversity in Brazil. Rodriguésia 66: 1085-1113.

Biral, L. \& Prado, J. 2012. First record of Pellaea ovata (Pteridaceae) from Brazil. American Fern Journal 102: 83-85.

Carvalho, F.A.; Salino, A. \& Zartman, C.E. 2012. New country and regional records from the Brazilian side of Neblina Massif. American Fern Journal 102: 228-232.

Christenhusz, M.J.M.; Zhang, X.-C. \& Schneider, H. 2011. A linear sequence of extant families and genera of lycophytes and ferns. Phytotaxa 19: 7-54.

Cochran, A.T.; Prado, J. \& Schuettpelz, E. 2014. Tryonia, a new taenitidoid fern genus segregated from Jamesonia and Eriosorus (Pteridaceae). PhytoKeys 35: 23-43.

Dittrich, V.A.O.; Salino, A. \& Almeida, T.E. 2012. Two new species of the fern genus Blechnum with partially anastomosing veins from Northern Brazil. Systematic Botany 37: 38-42.

Forzza, R.C.; Baumgratz, J.F.A.; Bicudo, C.E. de M.; Canhos, D.; Carvalho Jr., A.A.; Costa, A.F.; Costa, D.P.; Hopkins, M.; Leitman, P.M.; Lohmann, L.G.; Lughadha, E.N.; Maia, L.C.; Martinelli, G.; Menezes, M.; Morim, M.P.; Nadruz, M.; Peixoto, A.L.; Pirani, J.R.; Prado, J.; Queiroz, L.P.; Souza, V.C.; Stehmann, J.R.; Sylvestre, L.S.; Walter, B.M.T. \& Zappi, D.C. (orgs.). 2010. Catálogo de plantas e fungos do Brasil. Vol. 1. Jardim Botânico do Rio de Janeiro, Rio de Janeiro. 870p. 
Góes-Neto, L.A. de A. \& Pietrobom, M.R. 2012. Novos registros de samambaias para a Amazônia Brasileira. Rodriguésia 63: 1151-1155.

Gonzales, J. \& Kessler, M. 2011. A synopsis of the neotropical species of Sticherus (Gleicheniaceae), with description of nine new species. Phytotaxa 31: 1-54.

Hirai, R.Y.; Rouhan, G.; Labiak, P.H.; Ranker, T.A. \& Prado, J. 2011. Moranopteris, a new neotropical genus of grammitid ferns (Polypodiaceae) segregated from Asian Micropolypodium. Taxon 60: 1123-1137.

Hirai, R.Y. \& Prado, J. 2012. Monograph of Moranopteris (Polypodiaceae). Pteridologia 4: 1-113.

Kessler, M. 2010. Biogeography of ferns. In: Mehltreter, K.; Walker, L.R. \& Sharpe, J.M. (orgs.). Fern Ecology. Cambridge University Press, Cambridge. Pp. 22-60.

Kieling-Rubio, M.A. \& Windisch, P.G. 2012. Elaphoglossum montanum, a new species from Southern Brazil. American Fern Journal 102: 78-82.

Labiak, P.H. 2011. Stenogrammitis, a new genus of grammitid ferns segregated from Lellingeria (Polypodiaceae). Brittonia 63: 139-149.

Labiak, P.H. 2013. Grammitid ferns (Polypodiaceae). I. Lellingeria. Flora Neotropica 111: 1-129.

Labiak, P.H.; Rouhan, G. \& Sundue, M.A. 2010. Phylogeny and taxonomy of Leucotrichum (Polypodiaceae): A new genus of grammitid ferns from the Neotropics. Taxon 59: 911-921.

Lehnert, M. 2012. A synopsis of the species of Cyathea (Cyatheaceae-Polypodiopsida) with pinnate to pinnate-pinnatifid fronds. Phytotaxa 61: 17-36.

Lehnert, M. 2013. Grammitid ferns (Polypodiaceae). II. Melpomene. Flora Neotropica 112: 1-121.

Lehnert, M. \& Weigand, A. 2013. A proposal to distinguish several taxa in the Brazilian tree fern Cyathea corcovadensis (Cyatheaceae). Phytotaxa 155: 35-49.

Link-Pérez, M.A. \& Hickey, J.R. 2011. Revision of Adiantopsis radiata (Pteridaceae) with descriptions of new taxa with palmately compound laminae. Systematic Botany 36: 565-582.

Martinelli, G. \& Moraes, M.A. (orgs.) 2013. Livro vermelho da flora do Brasil. Andrea Jakobsson / Instituto de Pesquisas Jardim Botânico do Rio de Janeiro, Rio de Janeiro. 1100p.

Matos, F.B. \& Mickel, J.T. 2014. The Brazilian species of Elaphoglossum section Polytrichia (Dryopteridaceae). Brittonia 66: 371-395.

Matos, F.B.; Smith, A.R. \& Labiak, P.H. 2010. A new species of Thelypteris (Thelypteridaceae) from southern Bahia, Brazil. Brittonia 62: 149-152.

Melo, L.C.N. \& Salino, A. 2012. New species of Elaphoglossum Schott ex J. Sm. (Dryopteridaceae) from Brazil. American Fern Journal 101: 261-264.
Mickel, J.T. 2015 (in press). Anemia. Flora Neotropica. Mittermeier, R.A.; Myers, N.; Thomsen, J.B.; Fonseca, G.A.B. da \& Olivieri, S. 1998. Biodiversity Hotspots and Major Tropical Wilderness Areas: Approaches to Setting Conservation Priorities. Conservation Biology 12: 516-520.

Mittermeier, R.A.; Robles-Gil, P.; Hoffmann, M.; Pilgrim, J.; Brooks, T.; Mittermeier, C.G.; Lamoreux, J. \& Fonseca, G.A.B. 2004. Hotspots Revisited. EMEX/ Agrupación Sierra Madre, Mexico City. 390p.

Moguel-Velázquez, A. \& Kessler, M. 2013. Grammitid ferns (Polypodiaceae). III. Alansmia. Flora Neotropica 113: 1-67.

Moran, R.C. 2008. Diversity, Biogeography, and Floristics. In: Ranker, T.A. \& Haufler, C.H. (eds.). Biology and evolution of ferns and lycophytes. Cambridge University Press, Cambridge. Pp. 367-394.

Moran, R.C.; Labiak, P.H. \& Sundue, M.A. 2010. Synopsis of Mickelia, a newly recognized genus of bolbitidoid ferns (Dryopteridaceae). Brittonia 62: 337-356.

Mynssen, C.M. \& Matos, F.B. 2012. Diplazium fimbriatum (Athyriaceae), a new species from Brazil. American Fern Journal 102: 167-173.

Mynssen, C.M. \& Sylvestre, L.S. 2013. Novelties in Diplazium (Athyriaceae) from South America. Systematic Botany 38: 910-914.

Øllgaard, B. 2012a. Nomenclatural changes in Brazilian Lycopodiaceae. Rodriguésia 63: 479-482.

Øllgaard, B. 2012b. New combinations in Neotropical Lycopodiaceae. Phytotaxa 57-22.

Pereira, J.B. \& Labiak, P.H. 2013. A new species of Isoetes with tuberculate spores from Southeastern Brazil (Isoetaceae). Systematic Botany 38: 869-874.

Pereira, J.B.; Windisch, P.G.; Lorscheitter, M.L. \& Labiak, P.H. 2012. Isoetes mourabaptistae, a new species from Southern Brazil. American Fern Journal 102: 174-180.

Prado, J. 1998. Pteridófitas do Estado de São Paulo. In: Bicudo, C.E.M. \& Shepherd, G.J. (eds.). Biodiversidade do Estado de São Paulo - 2. Fungos macroscópicos \& plantas. FAPESP, São Paulo. Pp 47-61.

Prado, J. \& Hirai, R.Y. 2011. A new combination in Pleopeltis and some nomenclatural notes related to illustrations validating fern names. American Fern Journal 100: 189-194.

Prado, J. \& Hirai, R.Y. 2013. Adiantum lindsaeoides (Pteridaceae), a new fern species from the Atlantic Rain Forest, Brazil. Systematic Botany 38: 28-31.

Prado, J. \& Sylvestre, L.S. 2010. As samambaias e licófitas do Brasil. In: Forzza, R.C.; Baumgratz, J.F.A.; Bicudo, C.E. de M.; Canhos, D.; Carvalho Jr., A.A.; Costa, A.; Costa, D.P.; Hopkins, M.; Leitman, P.M.; Lohmann, L.G.; Lughadha, E.N.; Maia, L.C.; 
Martinelli, G.; Menezes, M.; Morim, M.P.; Nadruz, M.; Peixoto, A.L.; Pirani, J.R.; Prado, J.; Queiroz, L.P.; Souza, V.C.; Stehmann, J.R.; Sylvestre, L.S.; Walter, B M.T. \& Zappi, D.C. (orgs.). Catálogo de plantas e fungos do Brasil. Vol. 1. Jardim Botânico do Rio de Janeiro, Rio de Janeiro. Pp. 69-74.

Prado, J.; Hirai, R.Y. \& Smith, A.R. 2014. Dryopteris huberi (Dryopteridaceae), an overlooked species, and a key for the species of Dryopteris in Brazil. Brittonia 66: 340-346.

Salino, A.; Fernandes, R.S. \& Pietrobom, M.R. 2011. Thelypteris amazonica sp. nov. (Thelypteridaceae). Nordic Journal of Botany 29: 1-4.

Salino, A.; Sousa, M.G.M. \& Arruda, A.J. 2014. Thelypteris indusiata (Thelypteridaceae), a new fern species from Amazonian Brazil. Phytotaxa 156: 279-284.

Schuettpelz, E.; Davila, A.; Prado, J.; Hirai, R.Y. \& Yatskievych, G. 2014. Molecular phylogenetic and morphological affinities of Adiantum senae (Pteridaceae). Taxon 63: 258-264.

Schwartsburd, P.B. 2014. The identity of Polypodium gyroflexum (= Pleopeltis gyroflexa, comb. nov. Polypodiaceae). American Fern Journal 104: 16-21.

Schwartsburd, P.B. \& Prado, J. 2014. Subspecies of Hypolepis rugosula (Dennstaedtiaceae; Pteridophyta) around the world: Morphological and biogeographic perspectives. Acta Botanica Brasilica 28: 206-226.

Schwartsburd, P.B. \& Smith, A.R. 2013. Novelties in Serpocaulon (Polypodiaceae). Journal of the Botanical Research Institute of Texas 7: 85-93.
Schwartsburd, P.B.; Boudrie, M. \& Cremers, G. 2012. Two new species of Hypolepis (Dennstaedtiaceae: Pteridophyta) from Mount Roraima region (N South America) and a revised key for the Guianan species. Fern Gazette 19: 1-9.

Schwartsburd, P.B.; Moraes, P.L. \& Lopes-Mattos, K.L.B. 2014. Recognition of two morpho-types in eastern South American brackens (PteridiumDennstaedtiaceae-Polypodiopsida). Phytotaxa 170: 103-117.

Spring, A.F. 1840. Lycopodineae. In: Martius, C.F.P. \& Eichler, A.G. (eds.). Flora Brasiliensis. Fleischer, Leipzig.Vol. 1, part 2, pp. 106-136.

Sturm, J.G. 1859. Ophioglossaceae, Marattiaceae, Osmundaceae, Schizaeceae, Gleicheniaceae et Hymenophyllaceae. In: Martius, C.F.P. \& Eichler, A.G.(eds.). Flora Brasiliensis. Fleischer, Leipzig. Vol. 1, part 2, pp. 137-303.

Sundue, M.A.; Hirai, R.Y. \& Prado, J. 2013. Rumohra glandulosissima (Dryopteridaceae) a new species from the Atlantic Rainforest, and revision of the species occurring in Brazil. Systematic Botany 38: 915-924.

Tryon, R.M. 1972. Endemic areas and speciation in tropical American ferns. Biotropica 4: 76-84.

Vasco, A. 2011. Taxonomic revision of Elaphoglossum subsection Muscosa (Dryopteridaceae). Blumea 56: 165-202.

Vasco, A.; Mickel, J. T. \& Moran, R.M. 2013. Taxonomic revision of the neotropical species of Elaphoglossum sect. Squamipedia (Dryopteridaceae). Annals of the Missouri Botanical Garden 99: 244-286. 
